\title{
Performance and Learning in Virtual Work Teams: Comparing Brazilians and Argentineans
}

\section{Desempeño y Aprendizaje en Equipos Virtuales de Trabajo: Comparando Brasileños y Argentinos}

\author{
Sonia Maria Guedes-Gondim \\ Universidade Federal da Bahia
}

\author{
Katia Puente-Palacio \\ Universidade de Brasília
}

\author{
Jairo Eduardo Borges-Andrade \\ Universidade de Brasília
}

\begin{abstract}
The objective of this study was to analyze virtual teams from Brazil and Argentina. 181 Brazilians and 84 Argentineans responded to an electronic survey. Differences were found regarding the use of learning strategies, the need for training, and the perceived quality of interactions and effectiveness of virtual teams. The belief that the differences are more easily overcome in virtual teams than in traditional (co-located) teams explains to a greater extent the variance in the responses of Brazilians than Argentineans.

Keywords: performance, virtual team, learning strategies, virtual work.
\end{abstract}

\begin{abstract}
Resumen. El objetivo de este estudio fue el de llevar a cabo un análisis de los equipos virtuales de trabajo en Brasil y Argentina. 181 brasileños y 84 argentinos contestaron a un cuestionario on-line. Se encontraron diferencias significativas en el uso de estrategias de aprendizaje, en la necesidad de entrenamiento en relación a la percepción de la calidad de las interacciones, así como en la eficacia en el desempeño. La creencia de que las divergencias son más fácilmente superadas en los equipos virtuales que en los presenciales explica la mayor varianza encontrada en las respuestas de brasileños en comparación con los argentinos.

Palabras clave: desempeño, equipo virtual, estrategias de aprendizaje, trabajo virtual.
\end{abstract}

In work teams, there are performance requirements, and people need to use strategies in order to learn. Work processes can be distinct, when these teams are virtual. This topic has rarely been investigated in Latin America, although the number of these teams has been increasing in this region of the world. Moreover, virtual teams break geographical boundaries and foster organizational networks, contributing to a new configuration of work processes around the world (Bell \& Kozlowski, 2002; Cummings \& Kiesler, 2008; Kanawattanachai \& Yoo, 2002; Kayworth \& Leidner, 2002; Morgeson, DeRue \& Karam, 2009; Rangolam \& Ballard, 2007). The key aspects that define virtual teams are: (1) interdependency of tasks and fixed or variable temporality (Guzzo \& Dickson, 1996; Schiller \& Mandviwalla, 2007; Townsend, DeMarie \& Hendrickson, 1998; West, Borril \& Unsworth, 1998); (2) the prevalence of computer-mediated communication (CMC) rather than face-to-face (Anawati \& Craig, 2006; Fiol \& O'Connor, 2005; Gibson \& Cohen, 2003; Griffith \& Neale, 2001); and (3) partial or total geographical dispersion (Ahuja \& Carley, 1999; Gibson \& Cohen, 2003; Griffith \& Meader, 2004).

The studies on virtual teams are divided into three

Correspondence on this article should be sent to the first author to the following address: Rúa Rodrigo Argolo, 293/502, CEP 41940220, Rio Vermelho, Salvador, Bahia, Brasil. Email: sggondim@ufba.br groups according to the review by Martins, Gilson, and Maynard (2004), whose focus may be: (1) on the characteristics of virtual teams, such as size, member skills (Kayworth \& Leidner, 2002), richness of the technologies used and member status (Owens, Neale \& Sutton, 2000; Sproull \& Kiesler, 1986); (2) on the processes, which seek to explore how teams plan objectives, define actions, and establish interpersonal relationships (Chidambaram, 1996; Dubrovsky, Kiesler \& Sethna, 1991; Huan, Wei, Watson \& Tan, 2002; Lebie, Rhoades \& McGrath, 1996; Mortensen \& Hinds, 2001; Ratcheva \& Vyakarnam, 2001); (3) on outcomes, that study affects (satisfaction) and performance (effectiveness, speed in decision making, and decision quality). Their review indicates gaps in the studies of virtual teams, among which we highlight the cultural and occupational context, the handling of affects in relations among members, learning, and the predictive value of perceived performance. Although some of these issues may have prompted research on co-located teams, it is yet to be verified that the results of such studies are confirmed for virtual teams, which have been the subject of greater research interest recently.

In Brazil, despite regional differences (40\% in the southeast and $16 \%$ in the northeast), typical of a nearly continental size country, more and more households have a computer (PNAD, 2007; PNUD: New Atlas of Human Development in Brazil, 2000). In 
$2009,36 \%$ of households had at least one computer. These households' Internet access increased 20\% over the past five years (América Economía, 2010). However, Brazil's standing still lags behind other countries in the Americas. In the U.S., over $80 \%$ of households have at least one computer or laptop, $63 \%$ in Chile, $49 \%$ in Argentina, and 45\% in Colombia. The number of Internet users in Latin America is growing at an annual rate of $41 \%$, the fastest in the world (http://www.solociencia.com/informatical influencia-internet-sociedad-actual-datosactuales.htm). The information on the use of computers and Internet access in this region of the world suggests a scenario that increasingly enables the use of new technologies for teamwork activities in Latin America.

Would there be differences in virtual-team work among Latin American countries, since they often ignore borders? What is the predictive value of variables of perceived quality of interaction, mastery of new technologies, and learning strategies at work, on the perceived performance of virtual teams compared to traditional ones, since the development of knowledge about teams began with focus on the latter? These two general questions guided the design of this research. The overall objective was to characterize the work of virtual teams in Brazil and Argentina, belonging to a continent that is growing exponentially in the use of new information technologies to mediate collaborative work, but having differing levels of use and distribution of virtual teams. This research also explores the associations between perceptions of performance, quality of affective interactions, and learning strategies used to manage the new technologies required in this way of working, comparing, when possible, virtual and co-located teams. The explanatory power of perceived interaction quality in relation to perceived team performance was also tested, comparing samples from both countries.

The particularity of technology plays a role of paramount importance in understanding the operation of virtual work teams. A strong effect is also expected in the attributes of its members. The increased use of virtual teams demands specific skills to cope with new technologies. Thus it is relevant to study what learning strategies people use to ensure job performance and maintain the quality of the interactions established.

Learning strategies can be cognitive, behavioral, and self-regulatory (Warr \& Allan, 1998). The first type involves the memorization of content, its logical organization to facilitate information retrieval, and analytical examination of this same content. Behavioral strategies are divided among seeking out interpersonal help, consulting written material, and practical application (trial and error). The third type involves emotional control to reduce anxiety and increase concentration, motivational control (to maintain interest in what will be learned), and self-assess- ment in the learning phase in order to redirect actions (Pantoja \& Borges-Andrade, 2009). Cognitive and behavioral strategies are positively related to gains in knowledge and to learning transfer and performance at work (Pantoja, 2004; Zerbini \& Abbad, 2003; Zerbini, 2007; Warr \& Allan, 1998).

Despite the significant growth in the use of new technologies throughout Latin America, the first hypothesis of this study is that there would be differences between Argentina and Brazil in the perceived need for training and in the varied use of behavioral learning strategies, required in handling new technology in virtual work teams.

The performance of work teams depends on the members' beliefs about the effectiveness of this mode of working (Puente-Palacios \& Borges-Andrade, 2005 ), on the satisfaction with this type of collaborative work (Barczak \& Wilemon, 2001), on the perceived absence of conflict in interpersonal relationships (Jehn, 1997; Leung, Liu \& Ng, 2005), and on the perception of task execution conflicts (Friedman, Tidd, Currall \& Tsai, 2000; Harris, Ogbonna \& Goode, 2008; Lira, Ripoll, Peiró \& Orengo, 2006; Lira, Ripoll, Peiró \& González, 2007), which may or may not encourage exchanges among the members (Martins \& PuentePalacios, 2010; Zorzona, Ripoll, Orengo, GonzálezNavarro \& Peiró, 2008). With regard to members' satisfaction, the effects of virtual interactions appear to depend on the nature of the task and on the composition of the team (Cappel \& Windsor, 2000). But in general, lower levels of satisfaction are seen in virtual teams (VT's), when compared to traditional co-located teams (Jessup \& Tansik, 1991; Straus, 1996; Thompson \& Coovert, 2002; Warkentin, Sayeed \& Hightower, 1997).

On the performance of virtual teams, the amount of time required to perform tasks is higher in comparison with traditional co-located teams (Cappel \& Windsor, 2000; Daly, 1993; Graetz et al., 1998; Hollingshead, 1996; Straus, 1996; Weisband, 1992). Results on the quality of decision making in virtual teams have been inconclusive. There may be no differences between virtual and traditional teams (Cappel \& Windsor, 2000), the latter may be better (Andres, 2002), or worse than the virtual (Schmidt, Montoya-Weiss \& Massey, 2001). The dispersion and cultural diversity of team members could lead to a low level of group identity with subsequent declining investment in the group, undermining the quality of performance (Shapiro et al., 2002). The results indicate, however, that it is not the difficulty of face-to-face communication and the lifespan of the team that undermine group identity, group membership perception, and performance, but the awareness of the diversity of nationalities and the perception of distance between members (Ferguson, 2010). That is, the communication problems (loss of nonverbal cues, for example) would not be the central problem in virtual teams, in comparison 
with co-located teams. Even though research findings conclude that the time spent on task completion is higher in virtual teams, and are not conclusive on decision making in virtual teams, the second hypothesis of this study is that information exchange is higher in virtual teams in order to reduce uncertainty, and therefore turns the decision-making process more agile.

The third hypothesis is that virtual teams are perceived as offering better quality in the interactions among its members than traditional teams. This is based on the assumption that objectivity in interactions and communications among virtual team members promotes greater coherence, focus on the task, less perception of conflict, and greater affective quality in interpersonal relationships.

The exchange of information within virtual teams furthers shared meaning, reduction of uncertainty about status, and work performance (Mathieu, Heffner, Goodwin, Salas \& Cannon-Bowers, 2000). There are three types of exchanges most common in virtual teams: normative, regulative, and cognitive (Scott, 1995). Normative information refers to the understanding of what the team values and expects of each member. Regulative concerns the organizational standards on structure, procedures, or processes in place. Cognitive information is linked to task performance.

Content analysis of e-mails exchanged by a working team over a three-month period showed that new members initially adopt an active search for regulative and cognitive information, enabling them to know what to do (task) and how to do it (organizational standards) (Ahuja \& Galvin, 2003). Those who have had previous experience with each other and with the media used exhibit increased effective use of the media (Reichers, Wanous \& Steele, 1994; Yoo \& Alavi, 1999). This indicates that when people already know one another, the environment becomes less uncertain, encouraging interactions and the fulfillment of tasks (Cummings \& Kiesler, 2008).

A study involving 1,345 employees working in 126 teams in 17 organizations, which sought to evaluate the effects of disagreement and cohesion in work teams on knowledge (learning) sharing and task performance, concluded that cohesion has a positive effect on the exchanges established (advice, for example) among members, furthering the sharing of views and the team's performance (Woerkom \& Sanders, 2009). In a sense, this contradicts empirical evidence from other studies, in which disagreement contributes to group learning (Ellis et al., 2003; Kasl, Marsick \& Dechant, 1997; Van Offenbeek, 2001).

The absence of nonverbal cues and other references that would help reduce uncertainty in interactions affects the intensity of the exchange of information to perform everyday activities such as decision making, especially related to task distribution and control. Therefore, the fourth hypothesis is that information exchange and decision making are the main types of activities used by virtual teams, because they would be collaborating to increase cohesion, group identity, and socialization of the team.

Case studies of companies with extensive experience in virtual teams, whose aim was to investigate if characteristics of national or occupational culture determined managerial challenges and employee satisfaction, concluded that occupational culture is more decisive than national culture in the perception of satisfaction among members of virtual teams (Mihhailova, 2009). Occupational culture reveals the values and identity associated with a specific professional or occupational group. Occupational communities generate shared values and similar views on the bases of common educational background, professional requirements, and contact with colleagues in the same occupation (Schein, 1996). The work practices and forms of communication of occupational groups vary according to: i) low or high context communication, ii) data-based reasoning or intuitive reasoning, iii) logical working method or creative working method, iv) analytical/meticulous reasoning or conceptual and abstract reasoning, and v) a more quantitative or qualitative methodological approach. Multidisciplinary teams thus pose an additional challenge for leadership (Owens, Neale \& Sutton, 2000; Schuffer et al., 2010), in converging into the same space and context, professions and occupations that have different profiles of participation and involvement in teamwork.

A recent survey of 243 university students in Hong Kong and the US, who were developing projects in virtual teams, concluded that regardless of the supposed cultural differences between countries considered collectivistic and individualistic, the work team members perceive virtual interaction as more difficult than faceto-face (Hardin, Fuller \& Davison, 2007). Cultural difference appeared only in regard to perceived self-efficacy and collective efficacy (of the team). Americans rely more on their individual effectiveness than do the Chinese, who tend to rely more on the collective. Despite these cultural differences, there is a reduction of the status effect in virtual teams, given the difficulty leaders have in affirming their leadership, which may help explain the perception of difficulty in virtual interactions (Sproull \& Kiesler, 1986).

The fifth, and final, hypothesis is that the educational background of virtual team members is associated with perceived performance effectiveness and will exert more influence than will nationality. The assumption is that in spite of differences in the use and dissemination of new technologies in the work contexts of Argentina and Brazil, occupational culture (area of specialization) would exert a more decisive role as a predictor of perceived performance, since the context of professional socialization offers a more defined pattern of how to deal with new technologies than does inhabiting a given country. 


\section{Method}

\section{Sample}

In an electronic survey, 181 Brazilians $(\mathrm{Br})$ and 84 Argentineans (Arg) participated. The Brazilian sample is characterized by permanent staff with a technical function $(\mathrm{n}=54 \%)$, of both sexes, belonging to private organizations $(\mathrm{n}=53 \%)$, and large-sized $(\mathrm{n}=61 \%)$, with a college-level education $(\mathrm{n}=96 \%)$, specializing in humanities and social sciences $(\mathrm{n}=66 \%)$, and working in the area of human resources $(n=26 \%)$. The Argentinean sample is characterized by women $(n=64 \%)$ service providers $(n=47 \%)$ and permanent staff $(n=42 \%)$, in private organizations $(n=66 \%)$, of both large-size $(n=36 \%)$ and small $(n=27 \%)$, collegelevel $(\mathrm{n}=83 \%)$, specialized in humanities and social sciences $(\mathrm{n}=48 \%)$, who occupy a technical function $(\mathrm{n}=45 \%)$, and work in finance $(\mathrm{n}=18 \%)$.

\section{Procedure}

The electronic questionnaire was organized into three parts. The first included data to characterize the sample, previously described. The second part, focused on the characterization of teamwork, included the following information: technologies used, frequency of use, types of tasks and communication, percentage of time devoted to virtual communication, types of interactions, time devoted to communication, and workspace. The third part gathered information about the necessity of training, behavioral strategies employed in learning to use technological tools, and perceptions about performance effectiveness and the affective quality of interactions, comparing virtual and traditional teams. These questions were answered using an agreement scale ranging from 1 (total disagreement) to 5 (total agreement). The electronic questionnaire was developed, using EFS Survey (Globalpark) software, in two languages, Portuguese (Br) and Spanish (Arg) (http://ww3.unipark.de/uc/ virtual), and remained available in the period from January to August 2010. The means of dissemination was the Internet, discussion lists, and sending messages to professional telecommuting groups. The difference of means tests ( $t$-test for independent samples) was used in order to compare the Brazilian and Argentinean samples. Linear regression analysis permitted exploration of the interaction relationships among country, educational level, function, behavioral learning strategies, perceived interaction quality, and perceived performance effectiveness. Regression measurements, on the overall sample, were used to test the predictive value of the key variables in relation to the perceived performance of virtual teams.

\section{Results}

Email, either professional or personal $(\mathrm{Br}=71$ and $63 \%$; Arg=69 and 68\%), is the mediated communication resource most used, followed by computer system telephony $(\mathrm{Br}=45 \% ; \mathrm{Arg}=40 \%)$. The difference between countries emerges in the use of instant messaging $(\mathrm{Br}=35 \%$; $\mathrm{Arg}=53 \%)$ in the virtual environment created by the organization. This may be explained by the fact that the Brazilian sample is heavily concentrated in workers at large companies. The intensity of the use of all the resources of technological mediation varies from 50 to $85 \%$ in Brazilians, except for video conferencing (41\%), and in Argentineans from 63 to $89 \%$, except for video conferencing $(8 \%)$ and the virtual environment of the organization ( $41 \%)$. Over $80 \%$ of the Brazilians have never received training, a percentage that drops to 67 when it comes to the virtual environment of the organization, while $60 \%$ of the Argentineans reported never having received training, dropping to $52 \%$ for the virtual environment.

Interactions occur mainly through texts $(\mathrm{Br}=89 \%$ and $\operatorname{Arg}=83 \%$ ); followed by audio, used more by Argentineans (56\%) than Brazilians (35\%). Both synchronous and asynchronous forms of communication are used $(\mathrm{Br}=45 \%$ and $\mathrm{Arg}=54 \%)$, more than $61 \%$ of the time to carry out temporary and permanent projects $(\mathrm{Br}=69 \%$ and $\mathrm{Arg}=71 \%)$. Information exchange is the main activity carried out in virtual teams $(\mathrm{Br}=91 \%$ and $\mathrm{Arg}=82 \%)$, almost every day $(\mathrm{Br}=73 \%$ and $\mathrm{Arg}=67 \%)$. The differences between the two countries begin to emerge from there. For Brazil, in second place comes the monitoring and tracking of activities and tasks $(80 \%$; daily $=55 \%)$; for Argentina, activity planning $(26 \%$; daily $=26 \%)$. For the Brazilians, decision making comes in last place $(49 \%)$, behind the distribution of tasks (73\%), planning (69\%), and meetings (56\%). The same occurs with regard to the Argentineans (decision making $=34 \%)$, but after meetings $(62 \%)$, distribution of tasks $(59 \%)$, and monitoring of tasks $(50 \%)$. Finally, co-worker interaction is the main mediation technology used, followed by interaction with customers $(\mathrm{Br}=95$ and $60 \%$; $\mathrm{Arg}=87$ and $74 \%)$.

In the test of the first hypothesis, it became clear that the data from Argentina showed lack of normality, reaching a maximum of -1.72 and minimum of 0.30 . According to the recommendations of Miles and Shevlin (2001), asymmetry values above 1.0, but less than 2.0, indicate a significant difference between the normal and the empirical distribution. While not invalidating the results, they bring instability to the model estimates. In the case of the Br sample, asymmetry values were less than 1 (largest -0.94 and smallest -0.028), allowing the conclusion that this was a normal distribution. Thus, the hypothesis was tested, holding the view that the observed data abnormality does not necessarily require transformations. The results revealed that the groups are different regarding the need for 
training and the use of behavioral strategies to gain mastery of work mediation technologies in virtual teams (see Table 1). tics of working in virtual teams as compared to colocated teams (alpha $=0.79$ ). The results reveal that the Argentinean sample showed a slightly more positive

Table 1. Need for Training and Use of Behavioral Learning Strategies

\begin{tabular}{|c|c|c|c|c|}
\hline \multicolumn{2}{|c|}{ Training Needs and Behavioral Learning Strategies } & \multirow{2}{*}{$\begin{array}{c}\mathrm{n} \\
159\end{array}$} & \multirow{2}{*}{$\frac{\text { Mean }}{2.74}$} & \multirow{2}{*}{$\begin{array}{l}\text { SD } \\
1.63\end{array}$} \\
\hline Formal training was unnecessary & Br. & & & \\
\hline & Ar. & 72 & 2.25 & 1.65 \\
\hline \multirow[t]{2}{*}{ I learned exchanging experiences } & $\mathrm{Br}$. & 159 & 3.54 & 1.47 \\
\hline & Ar. & 72 & 3.10 & 1.58 \\
\hline \multirow[t]{2}{*}{ I learned from reading } & Br. & 159 & 3.23 & 1.54 \\
\hline & Ar. & 72 & 3.74 & 1.54 \\
\hline \multirow[t]{2}{*}{ I learned by trial and error } & $\mathrm{Br}$. & 159 & 3.62 & 1.48 \\
\hline & Ar. & 72 & 4.02 & 1.14 \\
\hline
\end{tabular}

$* p<0.05$ for all differences.

The data in Table 1 reveal that the Brazilians, more than the Argentineans, considered company training dispensable and claim to have learned the use of technology by exchanging experiences with colleagues, while the Argentineans state they developed their competence mainly through trial and error, and readings.

The same procedure was used to test the second hypothesis. Although the differences may have shown a marginal significance $(p>.05 ;<.01)$, the decision was to take the results into account, since the Argentinean sample size may have influenced this result. The performance effectiveness variable was the result of grouping seven items about the perceived characteris- evaluation (Mean=3.35; $\mathrm{SD}=1.07)$ than the $\mathrm{Br}$ one (Mean=3.11; $\mathrm{SD}=0.89$ ) on work mediated by technology, compared to co-located team work.

Regarding the third hypothesis, the results did not show values higher than 1 , thereby confirming normal distribution. As for the behavior of the groups investigated, significant differences $(p<.01)$ were observed in the comparison of Brazilians and Argentineans regarding the perceived quality of interpersonal relationships through the mediation of new technologies.

The comparison of Argentineans and Brazilians regarding the item "In interactions mediated by information technologies, with co-workers, people share

Figure 1. Predicted Opinion on Sharing Feelings about Perceived Performance of Virtual Teams, as a Function of Country and Educational Level

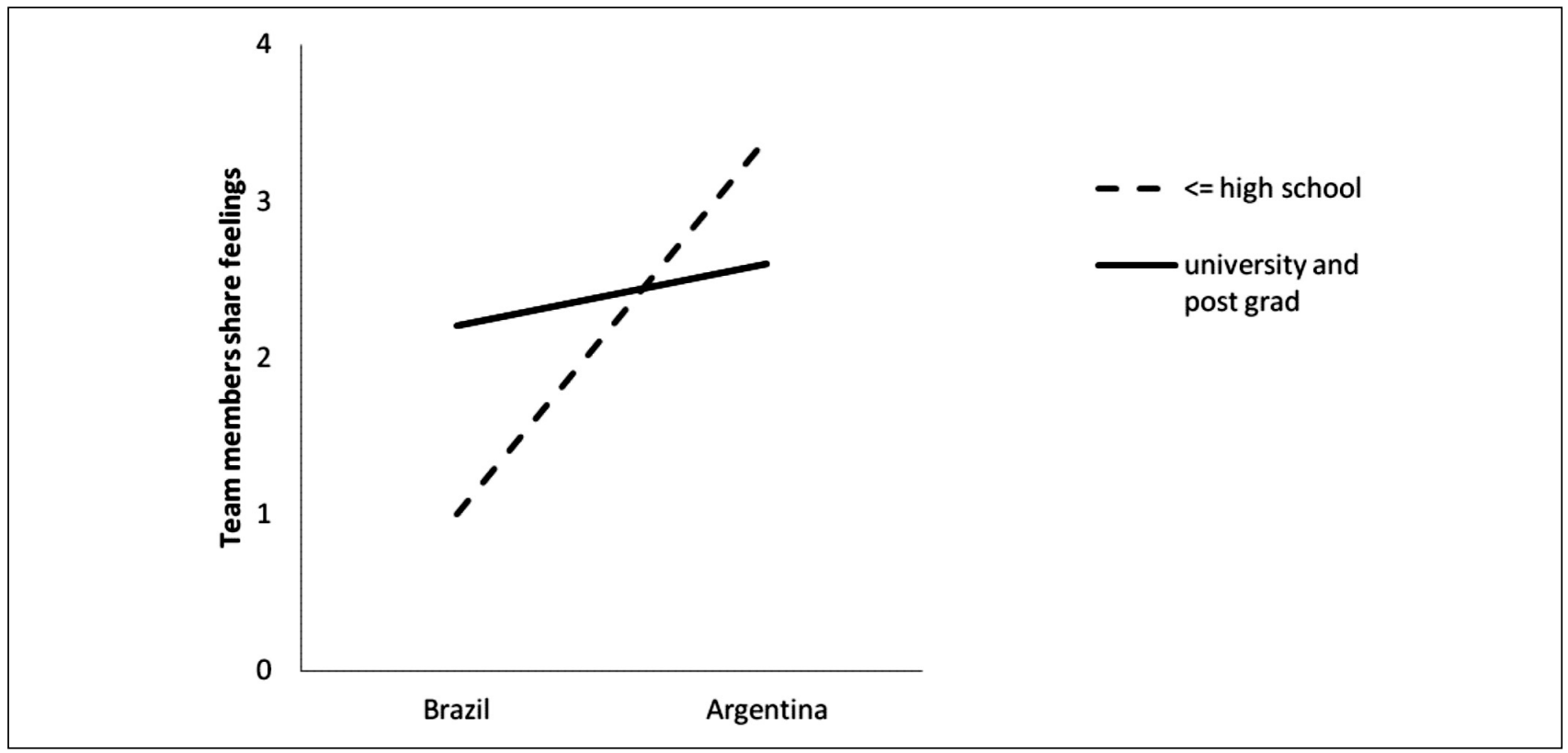


their personal feelings more than in face-to-face interactions" revealed that former (Mean=2.93; $\mathrm{SD}=1.36$ ) make more favorable and uniform (lower coefficient of variation) evaluations than the latter (Mean=2.28; $\mathrm{SD}=1.67$ ).

The results of the fourth hypothesis showed that the main tasks performed by virtual teams were information exchange ( $80 \%$ of the overall sample), followed by planning activities (64\%). Monitoring activities $(62 \%)$ and distribution of tasks $(61 \%)$ followed. Decision-making was the least reported (40\%).

The associated effects among the study variables, especially country, educational level, job or title, and area of expertise (occupational culture), and work team operation / performance perceptions were investigated, in order to test the fifth hypothesis. Only three interaction effects (see Figures 1, 2, and 3) were found. There was no interaction between country and specialization area that might indicate the importance of occupational culture in explaining the variance of responses.

The first effect derived from the interaction of the country and educational level variables, explaining $6.5 \%$ of the variance of perceived shared feelings in virtual teams as compared to co-located teams.

Figure 2. Predicted Opinion on Sharing Feelings about Perceived Performance of Virtual Teams, based on Country and Job Function

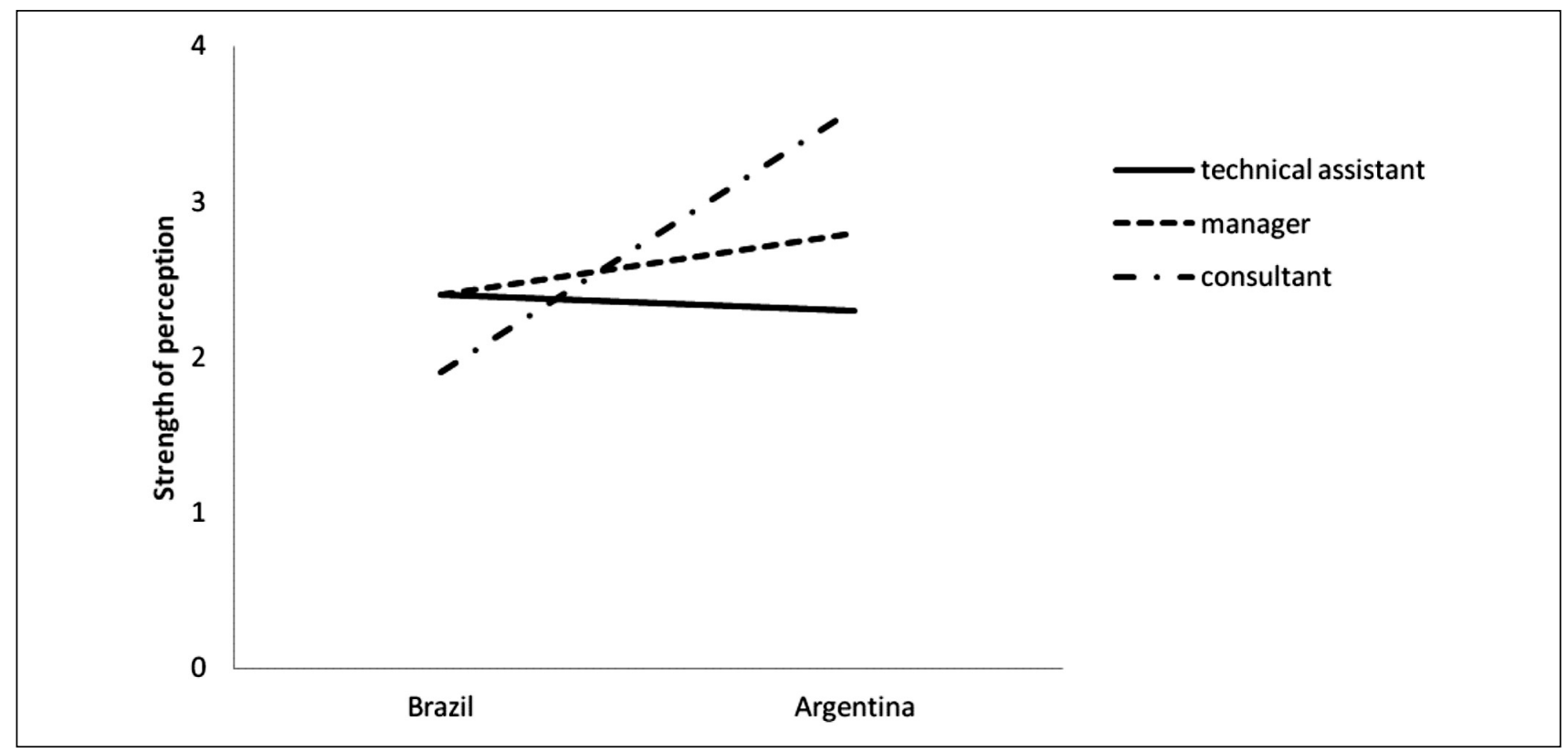

Figure 3. Predicted Opinion on the Need for Training concerning Perceived Performance of Virtual Teams, as a Function of Country and Gender

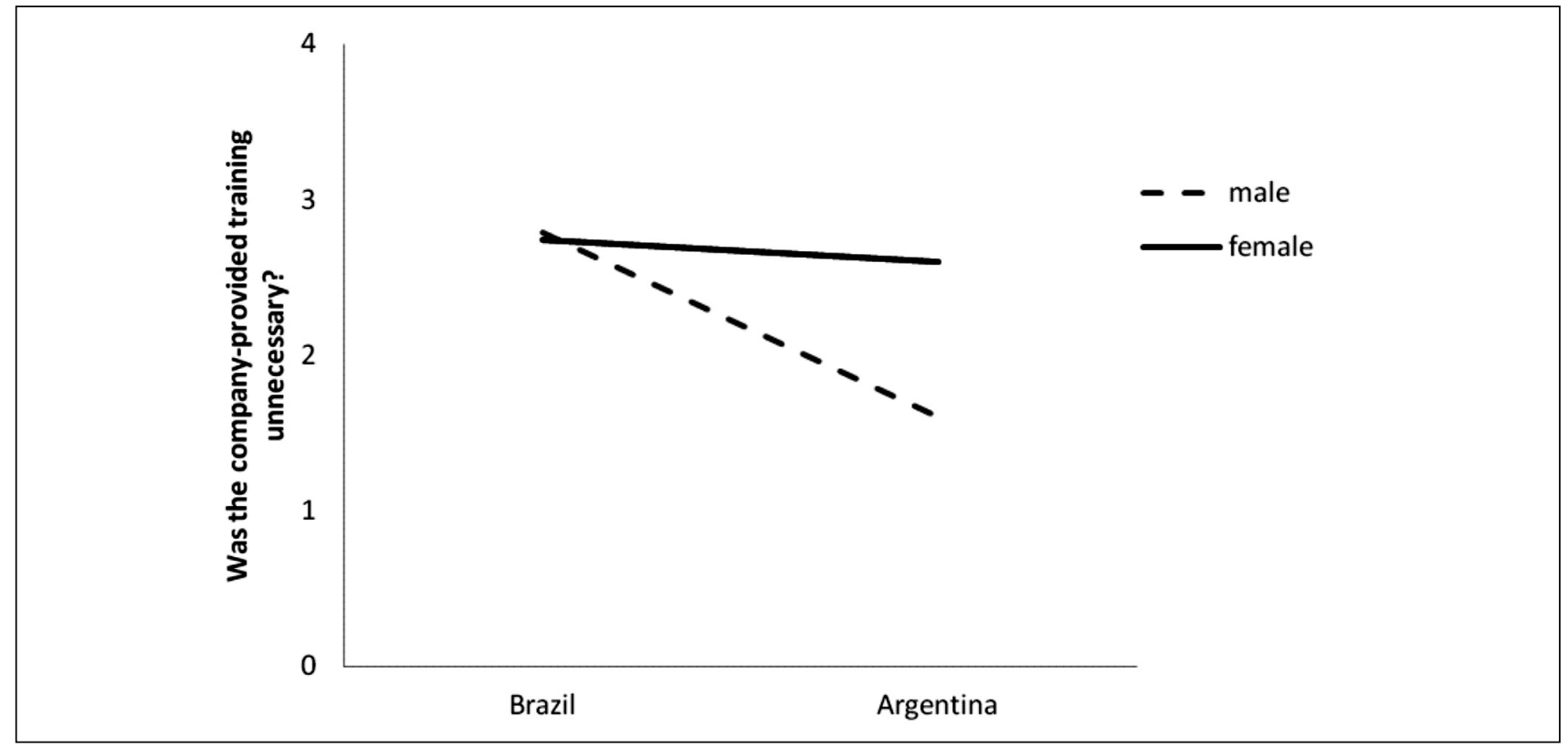


Country interacts with educational level, resulting in a visually and statistically significant correlation for the group of Argentineans who had at most a secondary level of education. The second effect was due to the interaction of the variables country and participant job function, explaining $6.8 \%$ of the perceptions of shared feelings. The difference arises between Brazilians and Argentineans who state that they perform in an advisory role. The third effect was due to the interaction of the variables country and gender, which explained $4.8 \%$ of the variance of responses about the training offered by the company being unnecessary for learning to use new technologies. The Brazilian males considered company-offered training far more expendable than did the Argentineans of the same sex.

Finally, the identification of patterns of explanation for the perceived performance of virtual teams was sought. Although the difference of this perception between groups of different nationalities may have been of marginal significance $(\mathrm{Br}$ mean $=3.10, \mathrm{SD}=.89$; Arg mean $=3.35 ; \mathrm{SD}=1.07)$, it was considered relevant to exploit them, given that the confidence interval for the averages of both groups showed no overlap $(\mathrm{Br}$ : CI-lower=2.96; upper $=3.25$; Arg: CI-lower $=3.26$, upper=3.77).

The initial focus of the analysis concentrated on the explanatory power of the perceived quality of virtual team interactions on the perception of performance effectiveness. Five items would refer to aspects such as sharing personal feelings (compared with face-to-face interactions) or even the case that differences are more easily overcome than in face-to-face interactions. Given that these items did not compose a unique underlying construct, while addressing the same theme, it was not possible to compose a factor, since they shared no more than $22 \%$ of the variance. For this reason, the five items were retained as independent predictors.

Table 2. Prediction of Perceived Virtual Team Performance Related to Perceived Quality of Affective Interactions

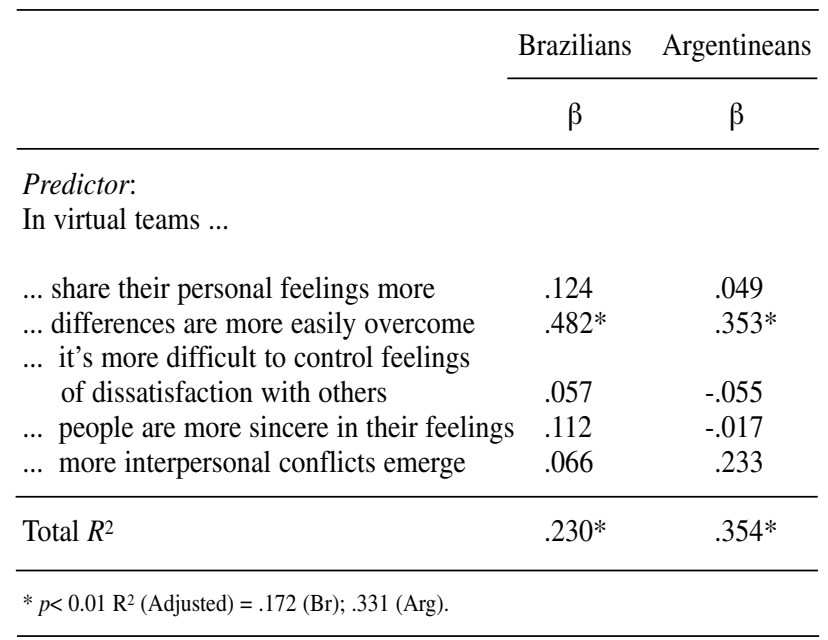

Two explanatory models, one for each country, were constructed. Each model showed significance in predicting the perceived performance of virtual teams, having reached in the case of the Br sample an explanation percentage of $35.4 \%$, while in the Arg sample this explanation was $23 \%$. Analysis of the differential contribution of each item revealed that only one of them showed a significant relationship, for both samples (see Table 2).

In order to test the explanatory power of behavioral learning strategies and the perceived training needs to master new technologies, each of the five items listed in the questionnaire were considered separately, since they were seen to share $14 \%$ at most. The model for the Br sample predicted $7.4 \%$ of perceived performance, while in the Argentinean sample this value was $22.7 \%$ (see Table 3).

Analysis of the independent relations of the predictors with the criterion variable showed that in the $\mathrm{Br}$ sample the only behavioral learning strategy of significant effect was that of personal readings and studies. In the Argentinean sample, despite the significance of the explanatory model $(p<0.05)$, analysis of the independent effects of the five items showed no significance for any of them. Thus, the set of learning strategies is what allows prediction of the perceived performance of virtual teams.

\section{Discussion}

The first finding that needs to be discussed concerns the explanation of the Argentineans' assessment of a greater need for training than the Brazilians'. Despite the widespread use of new technologies among the general population having been, higher in Argentina than in Brazil (América Economía, 2010), the samples of the two countries are different, because while

Table 3. Prediction of Perceived Virtual Team Performance Based on Training Needs and Behavioral Learning Strategies

\begin{tabular}{lcc}
\hline & Brazilians & Argentineans \\
\cline { 2 - 3 } & $\beta$ & $\beta$ \\
\hline Predictor: & & \\
Regarding learning the technologies: & & \\
& & \\
I learned by exchanging experiences with & & \\
$\quad$ my co-workers & .101 & .129 \\
Training was unnecessary & -.035 & .084 \\
I learned from reading and personal study & $.160^{*}$ & .100 \\
I was already proficient with the technologies & .129 & .211 \\
I learned on the job, by trial and error & .043 & .198 \\
\hline Total $R^{2}$ & .227 & .074 \\
\hline$* p=0.057$; $\mathrm{R}^{2}$ (Adjusted) $=.169$ (Br); .043(Arg). & & \\
\hline
\end{tabular}


women predominate in the first case, divided into permanent and contract service workers in small and large organizations, men within large organizations predominate in the $\mathrm{Br}$ sample. There may be a selection process in large organizations that seeks to incorporate professionals that already have a wider field of competencies. This would also explain the differences in the use of the learning strategies, trial and error, and reading, both more present in the Argentinean sample, since in the case of service providers there may be little support from co-workers.

Why Argentineans more favorably assess the effectiveness of virtual teams than Brazilians? This may be related to the intensity of sharing feelings, perceived more favorably by the former than the latter. The perceived efficacy of teams depends on the beliefs and the perception of conflict in interpersonal relationships (Jehn, 1997; Leung, Liu \& Ng, 2005). Sharing feelings is related to the group identity (Shapiro et al., 2002) and may be reflected in satisfaction with the team, helping to target the forms of mediation and to focus on task accomplishment. In large organizations $(\mathrm{Br}$ sample) one relies more on other types of social support, in comparison with work in independent services (Argentinean sample), which compels the individual to invest and rely more on one's own team.

The third point to be discussed concerns the activities performed by virtual teams. In accordance with what was anticipated and with previous studies, information exchange is the main form of mediation in the virtual team (Mathieu et al., 2002), having an important role in task execution and overall performance of the team (Ahuja \& Galvin, 2003; Woerkom \& Sanders, 2009). However, decision-making appeared in last place behind planning, assigning tasks, monitoring, and meetings. The explanatory assumption is that decision making in virtual teams must be understood as a process activity and not an endpoint. Decision making in virtual teams is thereby present in the performance of other activities such as, for example, planning and monitoring, as the process variables seem to be crucial in carrying out activities. In other words, when one has trouble finding other forms of support outside the established exchanges between team members, decision making becomes a constant in the daily work, to ensure continuity and compliance with established goals, and maintain the quality of interactions.

A primary limitation of this study concerns the differences in sample sizes, with normality problems in the distribution of responses from the Argentinean sample, indicating the need for further studies with wider samples. Another limitation relates to comparisons between virtual and co-located teams, in accordance with previous studies that concluded that interactions in virtual teams were more difficult and less satisfactory than in co-located teams (e.g., Hardin, Fuller \& Davison, 2007; Thompson \& Coovert, 2002). Additional studies are recommended to expand the possibilities for comparison of virtual and co-located teams, taking into account the specificities of each one, for example, the importance of established information exchange among the members to ensure the ultimate performance of the team, which appears to be distinct from the co-located team case. A third limitation relates to the lack of findings on the relationship between occupational culture (specialization area and professional training) and the perception of virtual teams (Mihhailova, 2009; Schein, 1996). Exploring the hypothesis that educational background has the capacity to promote a sharing of values and beliefs regarding the use of technology that affects performance may be considered of great heuristic value. The extensive study developed by means of survey may have been unable to capture this aspect of the phenomenon. Perhaps an experimental study would have more success in exploring the differences.

In conclusion, the first hypothesis was confirmed, for the differences between countries. Brazilians consider training less necessary than do Argentineans, and learn more with co-workers, while the latter learn more through practice (trial and error) and by consulting written material, although these differences could be explained by the different forms of formal work organization in the two samples studied. The second hypothesis was not confirmed. Only by considering marginal differences, can one conclude that Argentineans rate virtual teams higher than do Brazilians. The third hypothesis was partially confirmed. Only one of the five items of interaction quality showed a significant difference. Argentineans rate the sharing of feelings in the virtual team more highly than in the co-located team, when compared to Brazilians. The fourth hypothesis was also partially confirmed. The exchange of information was the main activity in both country samples. Decision making came in last among six activities proposed by the survey questionnaire. Likewise, the last hypothesis was partially confirmed. Only three interaction effects were found: country and educational level, country and job function on the perception of shared feelings in virtual teams compared to co-located teams, and country and gender on the perception that training is unnecessary. Concerning the patterns of explanation for the perceived performance of virtual teams, the belief that the differences are more easily overcome in virtual than in co-located teams explains to a greater extent the variance of the Brazilian than the Argentinean responses. Using the strategy of learning through reading and personal study explains the perceived performance of virtual teams in Brazil.

\section{References}

Ahuja, M. K., \& Carley, K. M. (1999). Network structure in virtual organizations. Organization Science, 10, 741-757. 
Ahuja, M. K., \& Galvin, J. E. (2003). Socialization in Virtual Groups. Journal of Management, 29, 161-185

América Economía: http://www.americaeconomia.com/ne gocios-industrias/el-36-de-los-hogares-en-brasil-tienen-lomenos-un-computador. Accessed on December 4, 2010.

Anawati, D., \& Craig, A. (2006). Behavioral adaptation within cross-cultural virtual teams. IEEE Transactions on Professional Communication, 49, 44-56.

Andres, H. P. (2002). A comparison of face-to-face and virtual software development teams. Team Performance Management, 8, 39-48.

Barczak, G., \& Wilemon, D. (2001). Factors influencing product development team satisfaction. European Journal of Innovation Management, 4, 32-36.

Bell, B. S., \& Kozlowski, S. (2002). A Typology of Virtual Teams: Implications for Effective Leadership. Group Organization Management, 27, 14-49.

Cappel, J. J., \& Windsor, J. C. (2000). Ethical decision making: A comparison of computer-supported and face-toface group. Journal of Business Ethics, 28, 95-107.

Chidambaram, L. (1996). Relational development in computer-supported groups. MIS Quarterly, 20, 143-165.

Cummings, J. N., \& Kiesler, S. (2008). Who collaborates successfully? Prior experience reduces collaboration barriers in distributed interdisciplinary research. Proceeding of CSCW'08, ACM press, November 8-12 (2008) San Diego, CA, USA.

Daly, B. L. (1993). The influence of face-to-face versus computer-mediated communication channels on collective induction. Accounting, Management, and Information Technology, 3, 1-22.

Dubrovsky, V., Kiesler, S., \& Sethna, B. (1991). The equalization phenomenon: Status effects in computer-mediated and face-to-face decision making groups. Human Computer Interaction, 6, 119-146.

Ellis, A. P. J., Hollenbeck, J. R., Ilgen, D. R., Porter, C. O. L. H., West, B. J., \& Moon, H. (2003). Team learning: Collectively connecting the dots. Journal of Applied Psychology, 88, 821-835.

Ferguson, M. (2010). The role of group membership perception and team identity in a virtual team's use of influence tactics. Social Science Research Network. http://papers. ssrn.com/sol3/papers.cfm?abstract_id=602047 accessed in October 2010.

Fiol, C., \& O'Connor, E. (2005). Identification in face-toface, hybrid, and pure virtual teams: Untangling the contradictions. Organization Science, 16, 19-32.

Friedman, R. A., Tidd, S. T., Currall, S. C., \& Tsai, J. C. (2000). What goes around comes around: the impact of personal conflict style on work conflict and stress. International Journal of Conflict Management, 11, 32-55.

Gibson, C. B., \& Cohen, S. G. (2003). Virtual Teams That Work: Creating Conditions for Virtual Team Effectiveness. San Francisco: Jossey-Bass.

Graetz, K. A., Boyle, E., Kimble, C., Thompson, P., \& Garloch, J. (1998). Information sharing in face-to-face, teleconferencing and electronic chat groups. Small Group Research, 29, 714-743.
Griffith, T. L., \& Meader, D. (2004). Prelude to virtual groups: Leadership and technology in semi-virtual groups. In D. Pauleen (Ed.), Virtual teams: Projects, protocols and processes (pp. 231-254). Hershey, PA: Idea Group.

Griffith, T. L., \& Neale, M. (2001). Information processing in traditional, hybrid, and virtual teams: From nascent knowledge to transactive memory. Research in Organizational Behavior, 23, 379- 421.

Guzzo, R. A., \& Dickson, M. W. (1996). Teams in Organizations: Recent Research on Performance and Effectiveness. Annual Review of Psychology, 47, 307338.

Hardin, A. M., Fuller, M. A., \& Davison, R. M. (2007). I Know I Can, But Can We? Culture and Efficacy Beliefs in Global Virtual Teams. Small Group Research Sage Publications, 38, 130-155.

Harris, L. C., Ogbonna, E., \& Goode, M. M. H. (2008). Intra-functional conflict: an investigation of antecedent factors in marketing functions. European Journal of Marketing, 42, 453-476.

Hollingshead, A. B. (1996). Information suppression and status persistence in group decision making. Human Communication Research, 23, 193-219.

Huang, W. W., Wei, K. K., Watson, R. T., \& Tan, B. C. Y. (2002). Supporting virtual team-building with a GSS: An empirical investigation. Decision Support Systems, 34, 359-367.

International Data Group Inc.: http://www.solociencia.com/ informatica/influencia-internet-sociedad-actual-datosactuales.htm. Accessed on December 4, 2010.

Jehn, K. A. (1997). A qualitative analysis of conflict types and dimensions in organizational groups. Administrative Science Quarterly, 42, 530-558.

Jessup, L. M., \& Tansik, D. A. (1991). Decision making in an automated environment: The effects of anonymity and proximity group decision support system. Decision Sciences, 22, 266-279.

Kanawattanachai, P., \& Yoo, Y. (2002). Dynamic nature of trust in virtual teams. Journal of Strategic Information Systems, 11, 187-213.

Kasl, E., Marsick, V. J., \& Dechant, K. (1997). Teams as learners: A research-based model of team learning. The Journal of Applied Behavioral Science, 33, 227-246.

Kayworth, T. R., \& Leidner, D. E. (2002). Leadership effectiveness in global virtual teams. Journal of Management Information Systems, 18, 7-40.

Lebie, L., Rhoades, J. A., \& McGrath, J. E. (1996). Interactions process in computer-mediated and face-toface groups. Computer supported cooperative work, 4, 127-152.

Leung, M., Liu, A. M. M., \& Ng, S. T. (2005). Is there a relationship between construction conflicts and participants' satisfaction? Engineering, Construction and Architectural Management, 12, 149-167.

Lira, E., Ripoll, P., Peiró, J. M., \& González, P. (2007). The roles of group potency and information and communication technology in the relationship between task conflict 
and team effectiveness. A longitudinal study. Computers in Human Behavior, 23, 2888- 2903.

Lira, E., Ripoll, P., Peiró, J. M., \& Orengo, V. (2006). How do different types of intragroup conflict affect group potency in virtual compared face-to-face team? A longitudinal study. Behavior and Information Technology, 25, 1-8.

Martins, L. L., Gilson, L. L., \& Maynard, M. T. (2004). Virtual Teams: what do we know and where do we go from here? Journal of Management. 30, 805-835.

Martins, M. C. F., \& Puente-Palacios, K. (2010). O psicólogo e sua inserção em equipes de trabalho [The psychologist and his/her participation in work teams] In A. V. B. Bastos \& S. M. G. Gondim (Orgs.) O trabalho do psicólogo no Brasil (pp.200-222) Porto Alegre: Artmed.

Mathieu, J. E., Heffner, T. S., Goodwin, G. F., Salas, E., \& Cannon-Bowers, J. A. (2000). The influence of shared mental models on team process and performance. Journal of Applied Psychology, 85, 273-283.

Mihhailova, G. (2009). Management challenges arising from the use of virtual work. Baltic Journal of Management, 4, 80-93.

Miles, J., \& Shevlin, M. (2001). Applying regression and correlation. A guide for students and researchers. London: Sage Publications.

Morgeson, F. P., DeRue, D. S., \& Karam, E. P. (2009). Leadership in teams: A functional approach to understanding leadership structures and processes. Journal of Management, 36, 1-39.

Mortensen, M., \& Hinds, P. J. (2001). Conflict and shared identity in geographically distributed teams. International Journal of Conflict Management, 12, 212-238.

Owens, D. A., Neale, M. A., \& Sutton, R. I. (2000). Technologies of status management: status dynamics in email communications. In Neale, M. A., Mannix, E. A., \& Griffith, T. L. Research on Groups and Teams Vol. 3, Technology (pp 205-230). Greenwich, CT: JAI Press.

Pantoja, J. (2004). Estratégias de Aprendizagem no Trabalho e Percepções de Suporte à Aprendizagem Contínua [Learning strategies at work, and perceptions of support for lifelong learning]. Unpublished Doctoral Thesis. Universidade de Brasília, Brasília, Brasil.

Pantoja, M. J., \& Borges-Andrade, J. E. (2009). Estratégias de aprendizagem no trabalho em diferentes ocupações profissionais [Learning strategies at work in different professional occupations. Revista Administração de Empresas RAC Eletrônica (Online), 3, 41-62.

PNAD. (2007): http://www.ibge.gov.br/home/presidencia/ noticias/ Accessed on October 01, 2008.

PNUD: Programa das Nações Unidas para o Desenvolvimento. (2000). Atlas do Desenvolvimento. [UNDP: United Nations Development Program (2000). Atlas of Development].

Puente-Palacios, K. E., \& Borges-Andrade, J. E. (2005). O efeito da interdependência na satisfação de equipes de trabalho: um estudo multinível [The effect of interdependence on the satisfaction of work teams: a multilevel study]. Revista de Administração Contemporânea, 9, 57-78.
Rangolam, D. I., \& Ballard, D. I. (2007). The Meanings and Meaningfulness of Time in Virtual Work Practices http://wms-soros.mngt.waikato.ac.nz/Organizational Communication/Pre-conference.htm, accessed on October 10, 2010

Ratcheva, V., \& Vyakarnam, S. (2001). Exploring team formation processes in virtual partnerships. Integrated Manufacturing Systems, 12, 512-523.

Reichers, A. E., Wanous, J. P., \& Steele, K. (1994). Design and implementation issues in socializing (and resocializing) employees. Human Resource Planning, 17, 17-25.

Schein, E. H. (1996). Three cultures of management: the key to organizational learning, Sloan Management Review, $38,9-20$.

Schiller, S.Z., \& Mandviwalla, M. (2007). Virtual team research: an analysis of theory use and a framework for theory appropriation. Small Group Research, 38, 1259.

Schmidt, J. B., Montoya-Weiss, M. M., \& Massey, A. P. (2001). New product development decision-making effectiveness: Comparing individuals, face-to-face teams, and virtual teams. Decision Sciences, 32, 575-600.

Scott, W. R. (1995). Institutions and organizations. Thousand Oaks, CA: Sage.

Schuffer, M.L., Wiese, C. W., Salas, E., \& Burke, S. (2010). Leading one another across time and space: exploring shared leadership functions in virtual teams. Revista de Psicología del Trabajo y de las Organizaciones, 26, 3-17.

Shapiro, D. L., Furst, S., Spreitzer, G., \& Von Glinow, M. A. (2002). Transnational teams in an electronic age: Are team identity and high performance at risk? Journal of Organizational Behavior, 23, 455-467.

Sproull, L., \& Kiesler, S. (1986). Reducing social context cues: Electronic mail in organizational communication. Management Science, 32:1492-1512. Reprinted in Irene Grief (ed.), 1988, Computer-Supported Cooperative Work: A Book of Readings. San Mateo, CA: Morgan Kaufman.

Straus, S. G. (1996). Getting a clue: The effects of communication media and information distribution on participation and performance in computer-mediated and face-toface groups. Small Group Research, 27, 115-142.

Thompson, L. F., \& Coovert, M. D. (2002). Stepping up to the challenge: A critical examination of face-to-face and computer-mediated team decision making. Group Dynamics, 6, 52-64.

Townsend, A. M., DeMarie, S. M., \& Hendrickson, A. R. (1998). Virtual teams: Technology and the workplace of the future. Academy of Management Executive, 12, 17-29.

Van Offenbeek, M. (2001). Processes and outcomes of team learning. European Journal of Work and Organizational Psychology, 10, 303-317.

Warkentin, M. E., Sayeed, L., \& Hightower, R. (1999). Virtual teams versus face-to-face teams: An exploratory study of a web-based conference system: In K. Kendall (Ed.), Emerging Information Technologies: Improving Decisions, Cooperation, and Infrastructure (pp. 241262), Thousand Oaks, CA: Sage. 
Warr, P., \& Allan, C. (1998). Learning strategies and occupational training. International Review of Industrial and Organizational Psychology, 13, 84-121.

Weisband, S. (1992). Group discussion and first advocacy effects in computer-mediated and face-to-face decision making groups. Organizational Behavior and Human Decision Processes, 53, 352-380.

West, M., Borrill, C., \& Unsworth, K. (1998). Team effectiveness in organizations. International Review of Industrial and Organizational Psychology, 13, 1-48.

Woerkom, M., \& Sanders, K. (2009). The romance of learning from disagreement. the effect of cohesiveness and disagreement on knowledge sharing behavior and individual performance within teams. Journal of Business of Psychology. 25, 139-149.

Yoo, Y., \& Alavi, M. (1999). Media and group cohesion: Relative influences on social presence, task participation, and group consensus. MIS Quarterly, 25, 371-390.

Zerbini, T. (2007) Avaliação da Transferência de Treinamento em Curso a Distância. Tese de Doutorado. Ins- tituto de Psicologia, Universidade de Brasília, Brasília. [Evaluation of Transfer of Training in a Distance Learning Course. PhD Thesis].

Zerbini, T., \& Abbad, G. S. (2003). Avaliação de um Treinamento Via Internet: estratégias de aprendizagem, reações aos procedimentos e ao tutor, suporte à transferência e impacto do treinamento no trabalho [Evaluation of a Training Via the Internet: learning strategies, reactions to the procedures and to the tutor, support for the transfer and impact of training on the job.]. Anais do XXVII Encontro da Associação Nacional de Pesquisa e Pós-graduação em Administração. Atibaia, SP: Associação Nacional dos Programas de Pósgraduação em Administração. p. 1-16.

Zorzona, A., Ripoll, P., Orengo, V., González-Navarro, P., \& Peiró, J. M. (2008). Los procesos de influencia social en entornos virtuales y su incidencia sobre la eficacia grupal [Social influence processes in virtual environments and their impact on group effectiveness]. (2008). Revista Latinoamericana de Psicología. 40, 213-227.

Manuscript received. 12/01/2010 Revision received: 07/03/2011 Accepted: 07/03/2011 